\title{
Políticas de inclusão e combate ao racismo: os desafios do debate sobre ações afirmativas no Brasil \\ Laura Moutinho e Márcia Lima
}

A sociedade brasileira enfrenta, atualmente, um intenso e tenso debate sobre a implementação de políticas afirmativas para a população negra. Um dos aspectos mais controversos e, portanto, com maior visibilidade no debate público, é a implementação do sistema de cotas no Ensino Superior, apesar de tais políticas não se restringirem a esse tipo de atuação. Embora o projeto de lei que institui o sistema de cotas nas universidades ainda esteja em tramitação, muitas universidades públicas (federais, estaduais e municipais) se anteciparam e, portanto, já estão discutindo sua implementação.

A revista Cadernos de Campo traz, nesta edição, uma contribuição importante a esse tema com a publicaçấo da mesa "Políticas de Inclusão", onde foram discutidas as políticas de acesso dos negros ao sistema universitário.

Como pode ser observado na leitura deste volume, o processo de implementação das políticas afirmativas tem gerado muitas controvérsias que envolvem questóes das mais diversas perspectivas (jurídicas, sociais e identitárias) mobilizando a participação de diferentes atores sociais. Um dos aspectos que chama atençâo neste debate é o rompimento com certa tradiçáo de silêncio da sociedade brasileira sobre as relações raciais.

As distintas posições encontradas neste debate podem ser sintetizadas em algumas questôes de fundo: os limites entre cor e classe no
Brasil e as questôes relacionadas à classificação de cor, dois aspectos clássicos dos estudos sobre o tema.

Em primeiro lugar, vale ressaltar que o ponto de discordância principal não se dá no reconhecimento de que há uma situação de desigualdade racial no Brasil e de que é necessário buscar formas de corrigi-la. Há, entretanto, pontos de tensão em relação a duas questôes: como construir tais políticas e quais serão seus efeitos nas relaçôes raciais brasileiras.

Em segundo lugar, o conflito se dá em torno da viabilidade ou não de uma política anti-racista não racialista. Por um lado, argumenta-se que tal mecanismo é inevitável para combater as desigualdades raciais, pois políticas focais baseiam-se na identificação de seus potenciais beneficiários. Por outro lado, argumenta-se que há um paradoxo neste modelo: assumir a idéia de raça para combater o racismo. A leitura deste número trará ao leitor subsídios para pensar e chegar às suas próprias conclusôes.

Por fim, é preciso destacar um aspecto crucial para o avanço deste debate. Um dos seus principais efeitos tem sido uma excessiva polarização em torno da questão das cotas, em detrimento da possibilidade de discutir outras experiências de enfrentamento do racismo e das desigualdades raciais, gerando uma indistinção entre este sistema e as Açóes Afirmativas. É importante ressaltar que há uma extensa pauta sobre formas de inclusão e diminuição 
238 | Laura Moutinho e Márcia Lima

das desigualdades raciais que devem ser inse- buir para o avanço do tratamento da questão ridas no debate público e, desta forma, contri- $\quad$ racial no Brasil.

\section{autor Laura Moutinho}

Professora do Departamento de Antropologia/USP

Doutora em Antropologia Social/IFCS-UFRJ

\section{autor Márcia Lima}

Professora do Departamento de Sociologia/USP

Doutora em Sociologia/UFRJ

Recebido em 15/01/2008

Aceito para publicação em 15/01/2008 